\title{
ZAKAT PROFESI DAN ZAKAT SAHAM PERUSAHAAN SOLUSI ANGGARAN PENDIDIKAN NASIONAL
}

\author{
Dr. H. Khairan Muhammad Arif, M.Ed \\ Khairanmarif.fai@uia.ac.id \\ (Dekan Pakultas Agama Islam Universitas Islam As-Syafi'iyah Jakarta)
}

\begin{abstract}
Abstrac: The Purpose of the research in this paper is presented scientifically and historically about the funcstioning of zakat in tackling social problems such as problems muslims budget education, zakat turns can be a solution, besides the national education budget state budget, let alone Indonesia is the largest muslim country in the world.

This paper writing method is to use a descriptif Histotical Method, the study of Islamic literatures about the concept and application of zakat in Islam as well as absorving the experience of Islamic Countries in the world in the practice of religious obligatory for budget education.
\end{abstract}

Keywords: Concept of Zakat, Zakat and the distribution of the budget for national education.

\section{A. PENDAHULUAN}

Zakat adalah sebuah system pengaman social islam yang telah dikenal umat Islam sejak pertama munculnya agama islam di dunia dan telah disosialisasikan serta diperaktekkan oleh rasulullah saw secara ketat kepada umat Islam yang mampu untuk mengentaskan kemiskinan, mensejahterakan rakyat, pemerataan keadilan dan sebagai system pengaman social yang paling efektif dari zaman Rasulullah sampai saat ini, walupun sebagian Negaranegara yang berpenduduk mayoritas muslim belum memperaktekkannya secara professional.

Zakat di beberapa Negara Islam telah menjadi solusi yang sangat efektif terhadap anggaran pendidikan, kesehatan dan social, beberapa Negara islam seperti Saudi Arabiah, Kuwait dan Mesir telah memperaktekkan zakat sebagai salah satu sumber anggaran pendidikan disamping wakaf, sehingga di Negara-negara ini biaya pendidikan gratis hampir diseluruh level pendidikan. Al-Azhar Mesir misalnya seluruh jenjang pendidkannya dibiayai 
oleh zakat dan wakaf sehingga biaya pendidikan dari TK sampai Perguruan Tinggi sangat murah bahkan gratis, baik dalam bentuk beasiswa maupun dalam bentuk subsidi penuh.

Oleh karenanya zakat yang telah terbukti dapat menjadi solusi anggaran pendidikan di samping angaran pendidikan nasional lainnya, karenanya provit Nasional yang bersumber dari zakat ini, harus menjadi perhatian serius pemerintah dalam hal ini Departeman Agama, sehingga zakat sebagai alternatif anggaran pendidikan nasional selain yang bersumber dari APBN dapat diterapkan dan diimplementasikan di Indonesia, yang memilki penduduk muslim terbesar di dunia yang tentunya memilki banyak muzakki (Wajib Zakat)dibanding dengan negara-negara lain di dunia.

\section{B. ANGGARAN PENDIDIKAN DAN PENGARUHNYA TERHADAP KUALITAS PENDIDIKAN}

Al-hamdulillah pemerintah telah menaikan anggaran pendidikan nasional sebesar 20\% dari tahun 2009, sesuai dengan keputusan UUD SISDIKNAS No 60 tahun 2003, namun belum terealisir hingga tahun 2009. Pemenuhan anggaran pendidikan sebesar 20 persen tersebut disamping untuk memenuhi amanat Pasal 31 Ayat (a) UUD 1945, juga dalam rangka memenuhi Putusan Mahkamah Konstitusi tanggal 13 Agustus 2008 Nomor 13/PUU-VI I 2008. Menurut putusan Mahkamah Konstitusi, selambat-lambatnya dalam UU APBN Tahun Anggaran 2009, Pemerintah dan DPR harus telah memenuhi kewajiban konstitusionalnya untuk menyediakan anggaran sekurang-kurangnya 20 persen untuk pendidikan ${ }^{1}$.

Akan tetapi anggaran pendidikan ini tetap menjadi kendala bagi perkembangan pendidikan nasional, disebabkan beberapa hal di ataranya adalah: efesiesnsi pengelolaan anggaran pendidikan, dan banyaknya lembaga-lembaga pendidikan swasta dibanding lembaga-lembaga pendidikan negeri di Indonesia, pendidikan swasta yang belum teralokasikan anggaran pendidikan nasional secara khusus, telah mengakibatkan rendahnya mutu pendidikan dan mahalnya biaya pendidikan. Bila anggaran pendidikan nasional mencapai 20 persen dari total APBN, mestinya seluruh jenjang pendidikan dasar dan

\footnotetext{
1 www.anggaran.depkeu.go.id
} 
menengah sudah bisa digratiskan, kalau anggaran pendidikan sebesar Rp 207 triliun itu sebagian besarnya dialokasikan untuk mensubsidi pendidikan dasar dan menengah, sebagaimana yang terjadi di Mesir puluhan tahun yang lalu telah menggratiskan seluruh level pendidikan dasar dan menengah sampai saat ini. Namun karena keputusan UUD 1945 di atas baru saat ini dilakasanakan, maka sangat sulit, menjadikan biaya pendidikan lebih murah dan dapat dijangkau seluruh rakyat Indonesia.

Perkembangan anggaran pendidikan nasional kita sebelum 2009 ternyata sangat mempengaruhi mahalnya biaya pendidiikan dan rendahnya mutu pendidikan nasional, karena sejak kemerdekaan sampai 2009 anggaran pendidikan kita adalah anggaran pendidikan terendah di seluruh dunia menurut Bank Dunia dan UNESCO. Anggaran pendidikan nasional sejak kemerdekaan sampai tahun 2009 adalah terkecil di dunia yaitu hanya 8-9\% tahun 1997 dan 10-11\% tahun 2000-2008, sementara jauh sebelumnya Thailand, Malaysia dan Negara Asia tenggara lainnya telah menganggarkan 20-23\% menurut data UNESCO dan Bank Dunia tahun $2003^{2}$.

Perkembanan anggaran pendidikan nasional dapat dilihat pada table berikut:

\begin{tabular}{|c|c|c|c|}
\hline NEGARA & $1945-1997$ & $2000-2007$ & 2008 \\
\hline Indonesia & $3,5-8 \%$ & $8-10,5 \%$ & $18,5 \%$ \\
\hline Thailand & $21 \%$ & $21-23 \%$ & $23 \%$ \\
\hline Malaysia & $21 \%$ & $23 \%$ & $23 \%$ \\
\hline
\end{tabular}

Sumber: UNESCO dan Bank Dunia 2003 dan Sumber lain

Lebih jelasnya dapat kita lihat perkembangan anggaran pendidikan nasional dari tahun 2005 sampai 2010 sebagaimana data yang diolah dari Departeman keuangan sebagai berikut:

${ }^{2}$ UNESCO and The World Bank, Education in Indonesia: Managing the Transition to Decentralization (Indonesia Education Sector Review), Vol. 2, 2003, P. 2-4 


\begin{tabular}{|c|c|c|}
\hline APBN & ALOKASI & RASIO \\
\hline 2005 & 33,40 triliun & $8,1 \%$ \\
\hline 2006 & 44,11 triliun & $10,1 \%$ \\
\hline 2007 & 53,07 triliun & $10,5 \%$ \\
\hline 2008 & 158,52 triliun & $18,5 \%$ \\
\hline 2009 & 207,41 triliun & $20,0 \%$ \\
\hline 2010 & 209,54 triliun & $20,0 \%$ \\
\hline
\end{tabular}

Sumber: KOMPASIANA 23 Desember 2009

Dampak negative dari rendahnya anggartan pendidikan nasional adalah:

1. Tingginya biaya pendidikan disemua level sehingga berimplikasi pada kebodohan anak-anak bangsa dan rendahnya kualitas SDM Indonesia dibanding dengan Negaranegara lain di dunia.

2. Menurunnya kwalitas pendidikan nasional yang berimlikasi pada meningkatnya angka pengangguran terdidik setiap tahun, Depnaker menyebutkan bahwa tahun 2007 angka pengangguran sarjana PT di Indonesia mencapai 409.890 sarjana.

3. Rendahnya partisipasi anak-anak miskin terhadap pendidikan, apalagi $70 \%$ penduduka Indonesia adalah orang miskin, ICMI mencatat bahwa partisipasi keluarga miskin terhadap pendidikan di Indonesia hanya 3\% tahun 2005 sementara anak-anak dari keluarga kaya $50-60 \%{ }^{3}$.

4. Alokasi anggaran pendidikan yang hanya diperuntukkan pada lembaga-lembaga pendidikan negeri telah memberikan kesulitan tersendiri pada pihak pendidikan swasta padahal hampir 70\% lembaga pendidikan di indodonesai adalah swasta, sehingga iuran SPP dan biaya pendidikan swasta semakin mahal dan sulit dijangkau oleh masyarakat ${ }^{4}$.

\footnotetext{
${ }^{3}$ Muslim Nasution, Green Education, For ICMI International Islamic Education Centre of Indonesia, Jakarta: ICMI , 2005.

${ }^{4}$ Khairan M. Arif, Al-Jamiaat al-islamiyah fi Indonesia, disertasi Doktor Fak. Tarbiyah, (Kairo: Universitas Liga Arab, 2008), hal 54.
} 


\section{ZAKAT DAN SOLUSI ANGGARAN PENDIDIKAN NASIONAL}

Salah satu mukjizat terbesar ajaran Islam adalah kewajiban zakat, dari sejak disyariatkannya zakat sampai hari ini, telah memberikan sumbangan tak ternilai bagi kehidupan umat islam terutama dalam menghapus kesenjangan sosial dan jarak antara simiskin dan sikaya. Kewajiban zakat yang merupakan rukun ketiga dari rukun-rukun islam ini memiliki keunikan yang tidak dimiliki oleh sistem ekonomi lain di dunia. Oleh karenanya diskursus tentang zakat adalah diskursus sistim ekonomi alternatif dalam perubahan kehidupan sosial umat setelah kegagalan ekonomi kapital selama ini.

Arti zakat yang sangat dikenal dikalangan para Ulama secara bahasa adalah "Bertambah, berkah, suci dan baik, adapun secara istilah zakat adalah Ukuran tertentu dari harta yang diwajibkan oleh Allah swt kepada orang mampu berzakat (mustahik)" 5 .

Perintah zakat disebutkan 30 kali dalam bentuk mandiri dalam Al-Qur'an sementara dalam bentuk bergandengan dengan perintah shalat disebutkan sebanyak 83 kali dalam AlQur'an, ini menunjukkan urgensi dan dan keutamaan zakat dalam kehidupan manusia, khususnya dalam kehidupan social.

\section{Hukum Zakat}

Zakat adalah rukun ketiga dari rukun-rukun islam, yang tidak sempurna keislaman seseorang bila tidak mengelurkan zakat, apakah mereka mampu atau tidak seperti zakat fitrah disetiap bulan ramadhan, adapun zakat mal diwajibkan bagi mereka yang telah memenuhi nishab zakat (ukuran minimal mengeluarkan zakat), baik yang memiliki haul (waktu mengelaurkan zakat) bulanan sperti zakat profesi, pertanian maupun yang haulnya tahunan seperti zakat emas dan perak, hasil perdaganagan dll. Hukum wajibnya zakat bagi orang yang mampu mengeluarkannya telah disepakati oleh seluruh mazhaba dalam islam.

Allah mewajibkan mengelaurkan zakat lewat beberapa ayat dalam al-qur'an seperti: "Ambillah zakat dari sebagian harta mereka, dengan zakat itu kamu membersihkan dan

\footnotetext{
${ }^{5}$ Yusuf Al-Qaradhawi, Fiqh Zakat, (Kairo: Maktabah Wahbah, 2006, jild 1) hal 55
} 
mensucikan mereka, dan mendoalah untuk mereka". (QS. At-taubah: 103), bahkan Allah mengancam orang-orang yang mampu mengelaurkan zakat dan terdapat hak orang miskin pada hartanya namun tidak mengeluarkan zakatnya dengan azab yang sangat pedih: "Dan orang-orang yang menyimpan emas dan perak dan tidak menafkahkannya pada jalan Allah, maka beritahukanlah kepada mereka, (bahwa mereka akan mendapat) siksa yang pedih". (QS. At-taubah: 34). Sebaliknya orang yang taat mengeluarkan zakat akan mendapat berkah dari hartanya, sebagaimana Allah Tabaraka wata'ala berfirman (di dalam hadits Qudsi): "Hai anak Adam, infaklah (nafkahkanlah hartamu), niscaya Aku memberikan nafkah kepadamu." (HR. Muslim)

\section{Jenis-jenis zakat kontenporer dan perannya dalam perkenomian umat}

Dalam tulisan dan kajian ini tidak akan dijelaskan jenis-jenis zakat klasik, seperti zakat emas dan perak, zakat hasil perdagangan, zakat fitrah, zakat pertanian, zakat barang tambang dan zakat hewan ternak. Tapi lebih fokus pada zakat kontenporer hasil ijtihad ulama modern yang ternyata telah memberikan hasil yang sangat besar dalam sejarah pengumpulan zakat di dunia dan telah sumbangan besar terhadap pengentasan kemiskinan, seperti zakat profesi dan zakat saham perusahaan. Kedua jenis zakat ini hanya dimiliki oleh para pengusaha dan para porfesional di zaman modern, penghasilan atau income mereka melebihi penghasilan para pedagang, pemiliki emas dan perak, para petani dan pemilik hewan ternak. Oleh karenanya bila jenis zakat ini tidak diaktualisasikan dan dilaksanakan oleh umat Islam, maka akan menzalimi para muzakki jenis zakat yang selama ini kita kenal, sebagaimana disebutkan di atas.

\section{a. Zakat Profesi}

Menurut Al-Qardhawi zakat profesi adalah zakat pekerjaan yang dilakukan oleh manusia, dari pekerjaan tersebut seseorang mendapkan hasil aatu income secara langsung tanpa terikat oleh orang lain yang terkait dengan pekerjaan tangan, ataupun keilmuannya. Dalam hal ini termasuk pula didalamnya income atau hasil profesi seseorang yang 
digelutinya, seperti dokter, insinyur, lawyer atau pengacara, ahli seni, penjahit, konsultan dan sebagainya". 6

Hukum zakat pekerjaan atau profesi ini menurut para Ulama seperti Abdurrahman hasan, Muhammad Abu Zahrah dan Abdul Wahhab Hallaf adalah boleh diambil zakatnya bila telah melalui masa haul (waktu tertentu wajibnya zakat) dan telah mencukupi nishabnya (kadar tertentu wajibnya zakat) ${ }^{7}$.

Al-Qardhawi berpendapat bahwa penghasilan bulanan seseorang, berupa gaji, seleri atau honor dan hasil bulanan lainnya adalah wajib dizakatkan setiap bulannya, tanpa menunggu berlalunya satu tahun seperti nishab zakat mal lainnya. Hal ini diqiyaskan dengan "Mal Al-Mustafad" yaitu harta yang dimanfaatkan oleh seoramg muslim kemudian dia mendapatkan hasil yang baru dari harta tersebut melelui sarana-sarana kepemilikan yang disyariatkan seperti bekerja dan berdagang.

Sebagian Sahabat Nabi saw menurut Al-Qardhawi telah mewajibkan zakat dari "Maal Mustafid" ini tanpa menyaratkan haul (waktu tertentu mengeluarkan zakat). Diantara para Sahabat yang berpendapat seperti ini adalah Ibnu Abbas, Ibnu Mas'ud, Muawiyah dan para Tabiin lainnya seperti Umar bin Abdul Aziz, Hasan Al-Bashri, Az-zuhri dan Al-Auzaiy, walaupun terdapat perbedaan pendapat dikalangan sahabat tentang hal ini. Oleh karenanya dalam kajian Al-Qardhawi bahwa pandangan yang palin rajih (kuat) dalam hal hukum dan haul zakat profesi adalah boleh, dan haulnya adalah setiap menerima gaji atau honor dari pekerjaan tersebut. ${ }^{8}$ Adapun nishab zakat profesi menurut Al-Qadhawi adalah setelah dikeluarkan semua kebutuhan pokoknya, karena pada dasarnya orang yang wajib berzakat adalah orang yang mampu. Sesuai firman Allah swt: "Mereka bertanya padamu wahai Muhamma bagaiman berzakat?, katakanlah berzakatlah dari Al-Afwu (harta yang lebih dari kebutuhan pokok)”(QS. Al-Baqarah: 219).

\footnotetext{
${ }^{6}$ Ibid, vol 1, hal 488

${ }^{7}$ Ibid, vol 1, hal 489

${ }^{8}$ Lihat Al-Qardhawi, Fiqh Zakat vol 1, hal 490-504
} 
Muhammad Al-Ghazali dan Al-Qardhawi berpendapat bahwa nishab zakat profesi ini sama dengan nishab zakat pertanian dan buahan, yaitu bila seorang petani telah menghasilkan 647 Kilo Gram hasil petaniannya, baik berupa beras, gandum dan lainnya. ${ }^{9}$

\section{b. Zakat Saham Perusahaan}

Saham secara definitif adalah surat bukti bagi persero (Pemegang Saham) dalam perseroan terbatas. Saham merupakan hak kepemilikan terhadap sejumlah tertentu kekayaan suatu perseroan terbatas (PT), besarnya hak kepemilikan seseorang atas harta perusahaan ditentukan oleh jumlah lembar saham yang dimiliki. Dalam ensiklopedi Indonesia disebutkan, bahwa saham adalah surat bukti yang menyatakan bahwa seseorang turut serta dalam suatu perseroan terbatas (PT). Jadi Zakat Saham adalah "Zakat kepemilikan surat bukti persero dalam suatu Perusahaan Terbatas (PT), sesuai dengan nilai dan jumlah lembar sahamnya".

Adapun Hukum dan ketentuan Zakat saham menurt para Ulama adalah sebagai berikut:

1) Bahwa interaksi atau bermuamalah dengan saham, seperti menerbitkan saham, jual beli saham dan kepemilikan saham boleh secara Syari'at. Dengan demikian pemilik saham wajib mengeluarkan zakatnya sesuai dengan nilai saham yang sesungguhnya dia miliki, sebagaimana zakat hasil perdagangan (Urudh Tijarah) ${ }^{10}$.

2) Saham Perusahaan yang wajib dikeluarkan zakatnya adalah meliputi Saham Perusahaan industri (PT yang bergerak dibidang pengadaan barang industri) maupun perusahaan perdagangan (PT yang bergerak dalan bidang investasi bisnis). Akan tetapi Perusahaan yang bergerak dibidang industri seperti pabrik, hotel, rumah sewa dll, hanya dikenakan zakat pada keuntungannya (Deviden) saja, bukan pada modal saham $^{11}$.

\footnotetext{
${ }^{9}$ Ibid, hal 512

${ }^{10}$ Wahbah Adz-zuhailiy, Mausu'ah Al-Fiqh Al-Islamiy wa Al-Qadhaya Al-Mu'ashirah, Vol 2, (Damaskus: Daru El-Fikr, 2010), hal 682

${ }^{11}$ Yusuf Al-Qrdhawi, Fiqh Zakat, vol 1, hal 523
} 
3) Perusahaan yang bergerak dalam bidang Investasi Bisnis, seperti Bank, Asransi dan sejenisnya, maka Zakat Sahamnya dikenakan pada Saham dan keuntungannya (Devidennya) sekaligus.

4) Nishab Zakat Saham sama dengan Zakat Hasil Perdagangan senilai 85 Gram Emas dan besarnya $2,5 \%$ dari total harga Saham+Deviden dan dikeluarkan setiap akhir tahun.

5) Saham yang akan dikeluarkan zakatnya, dinilai berdasarkan harga pasar/Bursa Saham, bukan berdasarkan harga pada waktu membelinya ${ }^{12}$.

6) Zakat Saham dikenakan berdasarkan nilai Saham Perusahaan secara kolektif, bukan berdasarkan nilai Saham pribadi, sehingga hitungan zakatnya berdasarkan nilai komulatif perusahaan secara kolektif.

7) Zakat Saham dikeluarkan oleh perusahaan bukan oleh masing-masing pemegang saham, namun dibolehkan apabila perusahaan memeberikan Zakat Saham kepada Pemegang Saham untuk diberikan kepada Amil Zakat tertentu atau orang tertentu yang diinginkannya ${ }^{13}$.

8) Keputusan Fatwa muktamar internasional pertama tentang zakat (Kuwait, Tahun 1403H/1983M) menyatakan bahwa jika perusahaan telah mengeluarkan zakatnya sebelum dividen dibagikan kepada pemegang saham, maka pemegang saham tidak perlu lagi mengeluarkan zakatnya.

\section{Alokasi Zakat Dalam Islam}

Hasil zakat yang telah diwajibkan bagi para muzakki harus dialokasikan kepada para mustahik zakat yang delapan ashnaf (golongan), sesuai dengan ketetapan Al-Qur'an sebagaimana berikut: artinya: "Sesungguhnya zakat-zakat itu, hanyalah untuk orang-orang fakir, orang-orang miskin, pengurus-pengurus zakat, Para mu'allaf yang dibujuk hatinya, untuk (memerdekakan) budak, orang-orang yang berhutang, untuk jalan Allah dan untuk

\footnotetext{
12 Ad-Zuhaili, Mausu'ah Fiqh Islamiy, vol 2 hal 642

13 Ibid, hal 696
} 
mereka yuang sedang dalam perjalanan, sebagai suatu ketetapan yang diwajibkan Allah, dan Allah Maha mengetahui lagi Maha Bijaksa” (QS. At-taubah: 60).

Dari ayat di atas jelas bahwa ada 8 (delapan) golongan yang berhak mendapat zakat yaitu:

a. orang fakir: orang yang Amat sengsara hidupnya, tidak mempunyai harta dan tenaga untuk memenuhi penghidupannya.

b. orang miskin: orang yang tidak cukup penghidupannya dan dalam Keadaan kekurangan.

c. Pengurus zakat: orang yang diberi tugas untuk mengumpulkan dan membagikan zakat.

d. Muallaf: orang kafir yang ada harapan masuk Islam dan orang yang baru masuk Islam yang imannya masih lemah.

e. Memerdekakan budak: mencakup juga untuk melepaskan Muslim yang ditawan oleh orang-orang kafir.

f. Orang berhutang: orang yang berhutang karena untuk kepentingan yang bukan maksiat dan tidak sanggup membayarnya. Adapun orang yang berhutang untuk memelihara persatuan umat Islam dibayar hutangnya itu dengan zakat, walaupun ia mampu membayarnya.

g. Pada jalan Allah (sabilillah): Yaitu untuk keperluan pertahanan Islam dan kaum muslimin. di antara mufasirin ada yang berpendapat bahwa fisabilillah itu mencakup juga kepentingan-kepentingan umum seperti mendirikan sekolah, rumah sakit dan lain-lain.

h. Orang yang sedang dalam perjalanan yang bukan maksiat mengalami kesengsaraan dalam perjalanannya.

Para Ulama dari dulu sampai sekarang telah meluaskan makna fi sabilillah dalam alokasi zakat mereka berpendapat bahwa fi sabilillah tidak terbatas pada orang-orang yang berjihad dijalan Allah semata, akan tetapi juga meliputi seluruh kegiatan social seperti membeli kafan, membangun sarana umum, renovشisi masjid, karena makna fi sabilillah 
adalah umum $^{14}$. Syekh rasyid Ridha dan imam Syalthout keduanya juga berpendapat bahwa makna Fi Sabilillah dapat diperluas meliputi seluruh kemaslahatan umum masyarakat yang dapat mengakan sebauh Negara dan bangsa termasuk di dalamnya pendidikan ${ }^{15}$.

Syekh Yusuf Al-Qaradhawi menyimpulkan dalam bukunya yang sangat monumental "Fiqh Zakat"16, bahwa golongan Fi Sabilillah memiliki arti yangh sangat luas termasuk dalam golongan ini adalah bahwa zakat dapat dialokasikan untuk kepentingan dan pembiayaan pendidikan termasuk sebagai anggaran pendidikan ${ }^{17}$.

Oleh karena itu zakat menurut para Ulama boleh disalurkan untuk anggaran pendidikan sebagaimana yang telah dilakukan oleh kaum muslim di masa para tabi'in seperti di masa Umar bin Abdul Aziz dari bani Umayah, di masa Bani Abbasiyah, dan di masa khilafah Utsmaniyah, bahkan mesir, Saudi Arabiyah, Kuwait dan sebagainya telah menalokasikan hasil zakat untuk para penunutut Ilmu dalam bentuk pemberian beasiswa dan subsidi pendidikan.

\section{PENGARUH ZAKAT TERHADAP ANGGARAN PENDIDIKAN}

Zakat sebagai takaful Ijtima'I (sistem penanggungan posial) memiliki fungsi social yang sangat efektif sebagai system pemerataan pendapatan masyarakat, sehingga kelompok kaya dalam masyarakat tidak menjadi zalim dan semakin kaya, sebaliknya simiskin tidak semakin tak berdaya karena sempitnya lapangan kerja dan sulitnya memperoleh modal usaha, karenanya zakat, wakaf, infak dan lainnya adalah system yang dapat mencairkan dan menghilangkan kesenjangan ini, sesuai dengan firman Allah swt:

\footnotetext{
14 Fakhruddin Ar-razi, dalam Yusuf Al-Qardhawi, Fiqh zakat, jilid 2, Op.cit, hal 656

15 Yusuf Al-Qardhawi, Fiqh zakat, jilid 2, Op.cit, hal 660

16 Buku Fiqh Zakat, adalah buku Islam yang sangat monumental di abad 21 sehingga penulisnya mendapat penghargaan King Faishal Award, karena manfaatnya yang sangat besar dalam dunia Islam, dalam buku ini Yusuf Al-Qardhawi, memberikan ijtihadnya dalam masalah zakat kontenporer, termasuk di dalamanya perluasaan makna ashnaf zakat dan jenis zakat baru yang dikenal dengan zakat profesi, disamping jenis-jenis zakat yang sudah kita kenal selama ini, zakat profesi ini telah dipraktekkan disebagian besar Negara Islam termasuk Indonesia yang telah memberikan manfaat zakat yang sangat signifikan kepada kaum dhua'afa.

17 Yusuf Al-Qardhawi, Fiqh zakat, jilid 2, Op.cit, hal 662
} 
Artinya: "Agar supaya harta itu jangan beredar di antara orang-orang kaya saja di antara kamu”. (Al-Hasyar: 7) .

Menurut Didin Khafidhudin zakat dalam kehidupan manusia dapat berfungsi sebagai berikut:

1. Sebagai perwujudan iman kepada Allah SWT, mensyukuri nikmat-Nya, menumbuhkan akhlak mulia dengan memiliki rasa kemanusiaan yang tinggi, menghilangkan sifat kikir dan rakus, menumbuhkan ketenangan hidup, sekaligus mengembangkan harta yang dimiliki.

2. Menolong, membantu dan membina kaum dhuafa (orang yang lemah secara ekonomi) maupun mustahik lainnya kearah kehidupannnya yang lebih baik dan lebih sejahtera, sehingga mereka dapat memenuhi kebutuhan hidupnya dengan layak, dapat beribadah kepada Allah SWT, terhindar dari bahaya kekufuran, sekaligus memeberantas sifat iri, dengki dan hasad yang mungkin timbul ketika mereka (orang-orang fakir miskin) melihat orang kaya yang berkecukupan hidupnya tidak memperdulikan mereka.

3. Sebagai sumber dana bagi pembangunan sarana maupun prasarana yang dibutuhkan oleh ummat Islam, seperti saran ibadah, pendidikan, kesehatan, sosial dan ekonomi, sekaligus sarana pengembangan kualitas sumber daya manusia (SDM) muslim.

4. Untuk mewujudkan keseimbangan dalam kepemilikan dan distribusi harta, sehingga diharapkan akan lahir masyarakat marhammah diatas prinsip ukhuwah Islamiyyah dan takaful ijtima'i.

5. Menyebarkan dan memasyarakatkan etika bisnis yang baik dan benar

Dalam studi kami zakat, infak, shadaqah dan wakaf adalah sumber pendanaan sosial islam yang sangat efektif dalam sejarah sosial peradaban Islam, di masa kejayaan Islam zakat dan wakaf sangat memberikan peran yang luar biasa dalam mensejahterakan dan memakmurkan bangsa, khususnya dalam bidang pendidikan dan keagamaan, sejak munculnya lembaga-lembaga pendidikan resmi dalam Islam seperti Universitas Zaitunah di Tunisia yang didirikan pada masa Bani Abbasiyah oleh Abdullah bin Al-Hijab tahun 
114H/732M, serta Universitas Al-Azhar di Mesir yang dibangun oleh dinasti fatimiyah tahun 132H/750M, Universitas Kardoba di Andalusia yang dibangun pada tahun 170H/786M oleh umat Islam Andalusia yang Hijrah dari Andalusia, Universitas Qarawiyin di Maroko, Universitas ini dibangun tahun $245 \mathrm{H} / 859 \mathrm{M}$ serta lembaga-lembaga pendidikan pada masa Harun Ar-rasyid seperti Baitul Hikmah dan Madrasah Nizhamiyah yang telah dibangun pada tahun $457 \mathrm{H} / 1065 \mathrm{M}^{18}$. Semua universitas di atas selain dibangun oleh dana pemerintah juga dari hasil zakat dan wakaf umat Islam sehingga dapat bertahan dan aktif sampai saat ini.

Oleh karenanya lembaga pendidkan yang didanai oleh zakat dan wakaf cenderung lebih lama bertahan dan aktif ketimbang lembaga-lembaga pendidikan yang dibiayai langsung oleh pemerintah, sebab zakat dan wakaf akan tetap mengalir dan membiayai pendidikan selama masyarakat itu ada dan menyadari kewajiban zakat dan wakaf ini, sebaliknya anggaran pendidikan dari pemerintah biasanya akan macet dan berhenti bila terjadi masalah politik dan ekonomi sebuah negara atau terjadinya perubahan rezim tertentu $^{19}$.

Sejarah mencatat bahwa wakaf tunai (cash wakaf) telah dijalankan sejak awal abad kedua hijriah. Imam Bukhari meriwayatkan bahwa Imam Az-Zuhri $(124 \mathrm{H})$ salah seorang ulama terkemuka dan peletak dasar tadwin al hadits telah menetapkan fatwa, bahwa basyarakat Muslim dianjurkan menunaikan wakaf menggunakan dinar dan dirham untuk pembangunan sarana dakwah, sosial, serta pendidikan umat Islam. Caranya, menjadikan uang itu sebagai modal usaha kemudian menyalurkan keuntungannya untuk wakaf.

Di luar negeri, zakat wakaf tunai sudah lama dipraktikkan. Misalnya di Mesir, Universitas Al Azhar menjalankan aktivitasnya dengan menggunakan dana zakat dan wakaf. Universitas tersebut mengelola gudang atau perusahaan di Terusan Suez. Universitas Al Azhar selaku nadzir atau pengelola wakaf dan zakat hanya mengambil hasilnya untuk keperluan pendidikan. Bahkan kemudian pemerintah Mesir meminjam dana zakat dan wakaf Al Azhar untuk operasionalnya. Di Qatar dan Kuwait, dana wakaf tunai dan zakat sudah

\footnotetext{
${ }^{18}$ Muhammad Al-Qatari, Al-Jami'aat Al-Islamiyah wadauruha fii Masiratil Fikri At-Tarbawiy, Kairo: Daarul Fikri Al-Arabiy, 1985) hal 70-118

${ }^{19}$ Khairan M. Arif, Al-Jamiaat al-islamiyah fi Indonesia, op.cit, hal 150
} 
berbentuk bangunan perkantoran. Areal tersebut disewakan dan hasilnya digunakan untuk kegiatan umat Islam.

Bisa dibayangkan bagaimana lembaga-lembaga pendidikan Islam semacam Al-Azhar University di Kairo, Universitas Zaituniyyah di Tunis, Universitas Qarawiyin di maroko serta Madaris Imam Lisesi di Turki begitu besar dan mampu bertahan hingga kini meski mereka tak berorientasi pada keuntungan. Mereka tak hanya mengandalkan dana pengembangan dari pemerintah, melainkan pada zakat dan wakaf tunai sebagai sumber pembiayaan segala aktivitas baik administratif maupun akademis.

Wallahu a'lam bisshawab

\section{DAFTAR PUSTAKA}

Khairan M. Arif, Al-Jamiaat al-islamiyah fi Indonesia, disertasi Doktor Fak. Tarbiyah, (Kairo: Universitas Liga Arab, 2008)

Muhammad Al-Qatari, Al-Jami'aat Al-Islamiyah wadauruha fii Masiratil Fikri AtTarbawiy, Kairo: Daarul Fikri Al-Arabiy, 1985)

Muslim Nasution, Green Education, For ICMI International Islamic Education Centre of Indonesia, Jakarta: ICMI , 2005.

UNESCO and The World Bank, Education in Indonesia: Managing the Transition to Decentralization (Indonesia Education Sector Review), Vol. 2, 2003 www.anggaran.depkeu.go.id

Yusuf Al-Qaradhawi, Fiqh Zakat Dirasah Muqaranah, Liahkamiha wafalsafatiha fii Dhau' Al-Qur'an wa As-Sunnah, (Kairo: Maktabah Wahbah, 2006)

Wahbah Adz-zuhailiy, Mausu'ah Al-Figh Al-Islamiy wa Al-Qadhaya Al-Mu'ashirah, (Damaskus: Daru El-Fikr, 2010) 